\title{
THE MANIPULATION OF HISTORY: CENSORSHIP IN FREEDOM OF INFORMATION ACT REQUESTS AT THE U.S. DEPARTMENT OF JUSTICE, FEDERAL BUREAU OF INVESTIGATION'
}

R.S. Rose ${ }^{2}$

\section{Abstract}

O Freedom of Information Act americano é gratuito até um número governo decidiu de páginas, mas as informações dadas está sujeita à censura desnecessária. Como essa supressão se relaciona com o Federal Bureau of Investigation, assumimos que grande parte desse controle de informações deve a sua existência a uma regra em casa, seja de facto ou de jure, que restringe qualquer coisa que mesmo parece que pode voltar a assombrar a agência. $\mathrm{O}$ suporte é fornecido por documentos liberados pelo FBI contrastados com os mesmos documentos disponibilizados a partir dos serviços de segurança do Canadá.

Key Words: Brazil. Canada. Censorship. Communism. Freedom of Information Act. Government Corruption. Federal Bureau of Investigation. USA.

1 An Earlier Version of this Work was Presented to the Academy of Criminal Justice Sciences Convention San Diego, CA, February 24, 2010.

2 Professor Visitante no Núcleo de Estudos das Américas, Universidade do Estado do Rio de Janeiro (UERJ). 
164 | InterAção

While conducting the research for "Johnny Project,"3 in January 1995, the American Federal Bureau of Investigation was contacted when it was learned that they might have a file on Johann Heinrich Amadeus de Graaf, commonly known, among 69 other names, as Johnny de Graaf. ${ }^{4}$ Indeed, the FBI did have such an archive, and we were instructed to initiate a request to the U.S. Department of Justice, Freedom of Information Action section to have the appropriate documents released. ${ }^{5}$ This article serves as a warning to those planning to use the seemingly open archive policy of the United States, first made available in 1966 when the act became law during the presidency of Lyndon B. Johnson. ${ }^{6}$ In theory, anyone, foreign or domestic, can request information under the statute. For academicians, it gave then and still gives now the impression of a largely untapped reserve of information. Such things, however, are never exactly what they seem.

De Graaf led a life worthy of a Hollywood movie: World

3 The published version is available in English in as Johnny: A Spy's Life (College Park: Penn State University Press, 2010) and in Portuguese as Johnny: A vida do espião que delatou a Rebelião Comunista no Brasil (Rio de Janeiro: Editora Record, 2010).

4 U.S. Department of Justice, Federal Bureau of Investigation [hereafter FBI], [J. Kevin 0'Brien], letter, August 18, 1995. At the time, 0'Brien was the chief of the Freedom of Information Privacy Acts Information Resources Division.

5 lbid., letters, January 24, 1995 and August 3, 1995.

6 Johnson was opposed to the bill for much of its ride through the legislature. He begrudgingly signed it, on July 4th, following a good deal of cajoling by California Democratic congressman John Moss. LBJ's resistance revolved around his dislike of allowing outsiders to scrutinize government archives. In the end, he affixed his signature to the measure with an accompanying statement cautioning against releasing military secrets, confidential advice, personnel files, investigative files and those items withheld out of executive privilege. "Freedom of Information at 40," The National Security Archive, [http://www.gwu.edu/ nsarchiv/NSAEBB/NSAEBB194/index. htm], accessed August 12, 2012. 
War I hero in the German navy, the Kaiserliche Marine, condemned to death for sedition, agitator and member of the German Communist Party, involved in the murder of Horst Wessel, educated in Moscow, M4 (Soviet Military Intelligence) officer, Communist operative on four continents, double agent up to and during World War II. The Soviets thought he was one of theirs, but since 1933, he actually worked for England's MI6. Nearly singlehandedly, he kept Brazil from going Communist in 1935. He travelled to Canada twice and assisted the Royal Canadian Mounted Police through much of the war to unmask local Nazis and Communists. He was the first to inform London of the location of the pocket battleship, Graf Spee.

As with other requests by other researchers, a Department of Justice/FBI stipulation was included with their initial response that some items might be restricted owing to various legal provisions of the Act. The Americans never used the word censorship, conceivably due to the feeling that such terminology was reserved for accusing other, less democratic nations of this or that transgression. Instead, the preferred synonym employed by Washington, DC was "redacted," a word that many would have to look up to comprehend. ${ }^{7}$ It was likewise pointed out that there was a backlog of cases in July 1995. They had received 14,450 requests requiring at least 5.2 years to be reviewed before their potential release. ${ }^{8}$ These last two sentences, of course, translated into the American's way to say that their review process could take considerable time, if ever, to complete.

7 The term is perhaps only exceeded in its hilarity by another U.S. government phrase, "expletive deleted."

8 J. Kevin 0’Brien], letter, August 18, 1995. 
166 | InterAção

The next communication from the FBI was nearly 18 months later when they wished to know if the release of documents were still desired. A response within 30 days was required or the request would be "administratively" dropped. ${ }^{9}$ A reply to the FBI confirmed that the documents were still desired, however, the FBI, for its part nearly a year later, could still not give a date or even an estimation of when the requested material might be available. ${ }^{10}$

On November 27, 2000, nearly six years after the initial communication to them, a partial liberation was made of the total number of releasable documents. The total number of items reviewed totaled 475 pages, of which 400 were made available. Possibly, the censored 75 pages consisted in a number of duplicates, but this could not be confirmed owing to the FBI's failure to report such information. ${ }^{11}$ Among the released pages, however, numerous names, sentences, and paragraphs were blacked out. Initially, the Department of Justice's Freedom of Information Act functionaries xeroxed the original document, and then censored the too sensitive sections with a thick Pentel before reproducing the copy. The copy of the copy was then sent to the requester.

The suppressed sections were deleted from release owing to Title 5 of the United States Code, Section 552 (Freedom of Information Act), Subsections (b)(1), (b)(2), (b)(7)(C), and (b)(7)(D). Subsection (b)(1) withholds information that is deemed to be "(A) spe-

9 lbid., letter, February 14, 1997.

10 lbid., letters, January 9, 1998.

$11 \mathrm{FBI}$, John M. Kolar [family name partially illegible], letter, June 13, 2001 [hereafter, Kolar letter]. Kolar's official title was the chief of the Freedom of Information Acts Section Office of Public and Congressional Affairs. 
InterAção | 167

cifically authorized under criteria established by an executive order to be kept secret in the interests of national defense or foreign policy and (B) are in fact properly classified pursuant to such executive order." Subsection (b)(2) removes from release items "related solely to the internal personnel rules and practices of an agency." Note that this latter subsection would conceivably allow functionaries to censor anything they so wished without fear of reprisal.

Subsections $(b)(7)(C)$ deletes from public scrutiny items that "could reasonably be expected to constitute an unwarranted invasion of personal privacy." Subsection (b)(7)(D) censorsmaterial that "could reasonably be expected to disclose the identity of a confidential source, including a state, local, or foreign agency or authority of any private institution which furnished information on a confidential basis, and, in the case of record or information compiled by a criminal law enforcement authority in the course of criminal investigation, or by an agency conducting a lawful national security intelligence investigation, information furnished by a confidential source."12

On June 13, 2001, another 244 out of 294 reviewed pages were made available. ${ }^{13}$ Following an appeal process, a further $75 \mathrm{pa}^{-}$ ges were released. ${ }^{14}$ This brought the total number of pages forwarded

12 FBI, "FBI Records: Freedom of Information Act/Privacy Act," < http://www.fbi.gov/ foia/foia-exemptions>, accessed February 4, 2012.

13 Kolar letter.

14 R.S. Rose to Co-Director [Richard L. Huff], U.S. Department of Justice [hereafter USDJ], June 19, 2001; U.S. Department of State, [Margaret P. Grafeld], letter, August 7, 2001; USDJ, [Richard L. Huff], letters, October 1, 2001; and July 29, 2004. At the time of her communication, Grafeld was the director of the IRM Programs and Services at the Department of State. Huff was the co-director of the Department of 
to this researcher on De Graaf to 719.

Having read the available literature on Johnny de Graaf, and having interviewed several persons from his family, this author was familiar with many of the events with which he had been involved. The FBI and other U.S. Government documents released thus contained many censored names that the author knew were blacked out, but should not have been so treated. Early in the process, it was explained that the rule used to release a name was based on three criteria: 1) obtaining permission from that individual, 2) showing that a person was diseased, or 3) proving that the person was over 100 years of age, and thus could reasonably assume to be diseased.

In order to prove that someone had passed away, on the other hand, the burden was placed squarely on the shoulders of the requester. U.S. government's functionaries would not lift a finger to search for someone on the internet-even when the internet source was provided confirming a death. All they had to do was click on the cyberspace address to check. Proof of death or age of $100+$ had to be provided at the time of the original FOIA request. American bureaucrats accepted death certificates, newspaper articles about someone's demise, or other documental sources attesting to a death or advanced age - at that time only. ${ }^{15}$ This would conceivably mean that if an applicant suspected the identity of a censored name in already released material, he or she would have to reapply with written proof of an individual's death, not an internet address to that proof, then wait 
InterAção | 169

years and pay the copying fees once again. Moreover, the applicant would have to repurchase the entire file and not just single pages in the file. ${ }^{16}$ Through this clever and expensive process, the number of researchers who reapply was/is obviously reduced.

Throughout the appeal process, moreover, government officials continued to use the same opening phraseology made infamous by the American auto insurance industry when denying a claim: "After careful consideration [italics mine] of this matter, I have determined that my original decision, ... was appropriate." ${ }^{17}$

There was no "careful consideration." In fact there was probably no consideration of any kind. What happened and continues to happen was and is a circling of American government wagons. This fact was borne out by two facts. First, the vast majority of names in the released documents sent to this researcher were expunged. This could lead one to believe that the persons who did the censoring simply covered up any name they ran across. As bureaucrats, they must have reasoned, "Why stick my neck out? It might come back to haunt me. So I'll just delete everything that looks interesting, relevant, or that I don't understand." Second, and most revealing, De Graaf

16 USDJ, [David M. Hardy], letter, May 27, 2005. At the time of his communication, Hardy was the U.S.

Department of Justice's section chief, Record/Information Dissemination Section, Records Management Division. A list of 91 -released pages with suspected erroneously censured names was prepared and sent to the Department of Justice. They indicated that a new request to see the entire file would have to be made. USDJ, [Richard L. Huff], letter, March 7, 2005.

17 USDJ, [Richard L. Huff], letters, September 29, 2004; March 7, 2005; and USDJ, [David M. Hardy], letter, May 10, 2006 [postmarked]. 
agreed to a series of FBI interrogations, that began in Montreal on March 10, 1952. Johnny had filed the paperwork to become a Canadian citizen three days before the arrival of the FBI agents in "La belle ville." ${ }^{18}$ As a condition for those interviews to take place, the RCMP supervised the meeting and received a typed, uncensored copy of the 101-page question and answer session. While the released FBI material had a version of this document, complete with censored names, the Canadian version, later released to the author, did not. Comparing the two accountings produced a total of 51 "redacted" names, some appearing more than once on the 101-page FBI copy.

\begin{tabular}{|c|c|c|c|}
\hline $\begin{array}{c}\text { Name deleted at least once on each FBI } \\
\text { page }\end{array}$ & $\begin{array}{c}\text { U.S. } \\
\text { censoring } \\
\text { statute }\end{array}$ & $\begin{array}{c}\text { Page } \\
\text { number, } \\
\text { FBI copy }\end{array}$ & $\begin{array}{c}\text { Page } \\
\text { number, } \\
\text { RCMP } \\
\text { copy } \\
\text { (vol. 4) }\end{array}$ \\
\hline Aitken, George & $(\mathrm{b})(7)(\mathrm{C})$ & 39 & 42 \\
\hline Aitken, George & $(\mathrm{b})(7)(\mathrm{C})$ & 40 & 44 \\
\hline Aitken, George & $(\mathrm{b})(7)(\mathrm{C})$ & 42 & 46 \\
\hline Aitken, George & $(\mathrm{b})(7)(\mathrm{C})$ & 44 & 47 \\
\hline Aitken, George & $(\mathrm{b})(7)(\mathrm{C})$ & 45 & 48 \\
\hline Aitken, George & (b)(7)(C) & 45 & 49 \\
\hline Berger, Harry ${ }^{19}$ & (b)(7)(C) & 55 & 60 \\
\hline Billy & (b)(7)(C) & 39 & 42 \\
\hline Billy & (b)(7)(C) & 40 & 43 \\
\hline Billy & (b)(7)(C) & 42 & 46 \\
\hline
\end{tabular}

18 Canada, document, "Petition for a Certificate of Canadian Citizenship by a British Subject," John Henry de Graff [petitioner], March 7, 1952, p. 2.

19 Harry Berger, one of the aliases of Arthur Ernst Ewert, was on the list of names originally provided to FBI bureaucrats, with proof of his death. 


\begin{tabular}{|c|c|c|c|}
\hline Brandler, Heinrich & $(\mathrm{b})(7)(\mathrm{C})$ & 9 & 8 \\
\hline Brandler, Heinrich & $(\mathrm{b})(7)(\mathrm{C})$ & 10 & 9 \\
\hline Bunzlau, Josef & $(\mathrm{b})(7)(\mathrm{C})$ & 88 & 95 \\
\hline Bunzlau, Josef & $(\mathrm{b})(7)(\mathrm{C})$ & 89 & 96 \\
\hline Cachin, Marcel & $(\mathrm{b})(7)(\mathrm{C})$ & 44 & 48 \\
\hline Cachin, Marcel & $(\mathrm{b})(7)(\mathrm{C})$ & 53 & 57 \\
\hline Dunker, Herman & & 17 & 17 \\
\hline Feix & $(\mathrm{b})(7)(\mathrm{C})$ & 71 & 77 \\
\hline Fischer, Ruth & $(\mathrm{b})(7)(\mathrm{C})$ & 9 & 8 \\
\hline Fischer, Ruth & $(\mathrm{b})(7)(\mathrm{C})$ & 10 & 8 \\
\hline Fischer, Ruth & $(\mathrm{b})(7)(\mathrm{C})$ & 11 & 10 \\
\hline Fischer, Ruth & $(\mathrm{b})(7)(\mathrm{C})$ & 11 & 11 \\
\hline Fischer, Ruth & $(\mathrm{b})(7)(\mathrm{C})$ & 12 & 11 \\
\hline Florin, Wilhelm & $(\mathrm{b})(7)(\mathrm{C})$ & 16 & 16 \\
\hline Frohlich, Paul & $(\mathrm{b})(7)(\mathrm{C})$ & 17 & 17 \\
\hline General Blucher [a.k.a Galem] & $(\mathrm{b})(7)(\mathrm{C})$ & 32 & 34 \\
\hline Gobbels, Jacob & $(\mathrm{b})(7)(\mathrm{C})$ & 48 & 52 \\
\hline Gobbels, Jacob & $(\mathrm{b})(7)(\mathrm{C})$ & 49 & 53 \\
\hline Gobbels, Jacob & $(\mathrm{b})(7)(\mathrm{C})$ & 52 & 56 \\
\hline Goldie & $(\mathrm{b})(7)(\mathrm{C})$ & 71 & 78 \\
\hline Hans & $(\mathrm{b})(7)(\mathrm{C})$ & 85 & 92 \\
\hline Harry [Hans Wilhelm] & $(\mathrm{b})(7)(\mathrm{C})$ & 85 & 92 \\
\hline Harry [Hans Wilhelm] & $(\mathrm{b})(7)(\mathrm{C})$ & 86 & 93 \\
\hline Harry [Hans Wilhelm] & $(\mathrm{b})(7)(\mathrm{C})$ & 89 & 96 \\
\hline Harry [Hans Wilhelm] & $(\mathrm{b})(7)(\mathrm{C})$ & 90 & 97 \\
\hline Harry [Hans Wilhelm] & $(\mathrm{b})(7)(\mathrm{C})$ & 92 & 99 \\
\hline Heckert, Fritz & $(\mathrm{b})(7)(\mathrm{C})$ & 46 & 50 \\
\hline Heckert, Fritz & $(\mathrm{b})(7)(\mathrm{C})$ & 47 & 50 \\
\hline Heckert, Fritz & $(\mathrm{b})(7)(\mathrm{C})$ & 47 & 51 \\
\hline Horstman, Dr. & $(\mathrm{b})(7)(\mathrm{C})$ & 18 & 18 \\
\hline
\end{tabular}




\begin{tabular}{|c|c|c|c|}
\hline Julien, Francisco & $(\mathrm{b})(7)(\mathrm{C})$ & 89 & 96 \\
\hline Junescu & $(b)(7)(C)$ & 34 & 37 \\
\hline Junescu & $(b)(7)(C)$ & 36 & 38 \\
\hline Kaganovich, Lavar & $(b)(7)(C)$ & 80 & 87 \\
\hline Kaganovich, Lavar & $(b)(7)(C)$ & 81 & 88 \\
\hline Kruerberg & $(b)(7)(C)$ & 12 & 12 \\
\hline Kuusinen, Otto & $(b)(7)(C)$ & 28 & 31 \\
\hline Ladislaw & $(b)(7)(C)$ & 56 & 61 \\
\hline Ladislaw & $(b)(7)(C)$ & 58 & 63 \\
\hline Lebowitsch [Leibovitch] & $(b)(7)(C)$ & 19 & 19 \\
\hline Lebowitsch [Leibovitch] & $(b)(7)(C)$ & 43 & 47 \\
\hline Losafsky & $(b)(7)(C)$ & 44 & 48 \\
\hline Manuilski, Dmitri & $(b)(7)(C)$ & 38 & 41 \\
\hline Manuilski, Dmitri & $(\mathrm{b})(7)(\mathrm{C})$ & 44 & 48 \\
\hline Manuilski, Dmitri & $(b)(7)(C)$ & 45 & 49 \\
\hline Manuilski, Dmitri & $(b)(7)(C)$ & 46 & 50 \\
\hline Manuilski, Dmitri & $(b)(7)(C)$ & 62 & 67 \\
\hline Manuilski, Dmitri & $(b)(7)(C)$ & 62 & 68 \\
\hline Manuilski, Dmitri & $(b)(7)(C)$ & 63 & 68 \\
\hline Manuilski, Dmitri & $(b)(7)(C)$ & 75 & 82 \\
\hline Manuilski, Dmitri & $(b)(7)(C)$ & 76 & 82 \\
\hline Manuilski, Dmitri & $(b)(7)(C)$ & 76 & 82 \\
\hline Maria & $(b)(7)(C)$ & 91 & 98 \\
\hline Marti & $(b)(7)(C)$ & 44 & 48 \\
\hline Marti & $(b)(7)(C)$ & 44 & 48 \\
\hline Max & $(b)(7)(C)$ & 80 & 87 \\
\hline $\begin{array}{c}\text { Mello, Dr. [Dr. Barbosa de Mello Ilvo } \\
\text { Meireles] }\end{array}$ & $(b)(7)(C)$ & 64 & 69 \\
\hline Mikoyan, Anastas & $(b)(7)(C)$ & 80 & 87 \\
\hline Milly & $(b)(7)(C)$ & 39 & 42 \\
\hline
\end{tabular}




\begin{tabular}{|c|c|c|c|}
\hline Milly & $(\mathrm{b})(7)(\mathrm{C})$ & 40 & 43 \\
\hline Milly & $(\mathrm{b})(7)(\mathrm{C})$ & 42 & 46 \\
\hline Milly & $(\mathrm{b})(7)(\mathrm{C})$ & 43 & 46 \\
\hline Milton [Eugene Dennis] & $(\mathrm{b})(7)(\mathrm{C})$ & 56 & 60 \\
\hline Milton [Eugene Dennis] & $(\mathrm{b})(7)(\mathrm{C})$ & 60 & 65 \\
\hline Milton [Eugene Dennis] & $(\mathrm{b})(7)(\mathrm{C})$ & 60 & 66 \\
\hline Milton [Eugene Dennis] & $(\mathrm{b})(7)(\mathrm{C})$ & 61 & 66 \\
\hline Milton [Eugene Dennis] & $(\mathrm{b})(7)(\mathrm{C})$ & 62 & 67 \\
\hline Molotov, Vyacheslav & $(\mathrm{b})(7)(\mathrm{C})$ & 80 & 87 \\
\hline Molotov, Vyacheslav & $(\mathrm{b})(7)(\mathrm{C})$ & 81 & 88 \\
\hline Munzenberg & $(\mathrm{b})(7)(\mathrm{C})$ & 14 & 13 \\
\hline Obuch, Dr. & $(\mathrm{b})(7)(\mathrm{C})$ & 18 & 18 \\
\hline Paulina & $(\mathrm{b})(7)(\mathrm{C})$ & 34 & 37 \\
\hline Pieck, William & $(\mathrm{b})(7)(\mathrm{C})$ & 9 & 8 \\
\hline Pieck, William & $(\mathrm{b})(7)(\mathrm{C})$ & 10 & 10 \\
\hline Pieck, William & $(\mathrm{b})(7)(\mathrm{C})$ & 18 & 19 \\
\hline Pieck, William & $(\mathrm{b})(7)(\mathrm{C})$ & 19 & 19 \\
\hline Plantz, Special Agent & $(\mathrm{b})(7)(\mathrm{C})$ & 23 & 25 \\
\hline Pollitt, Harry & $(\mathrm{b})(7)(\mathrm{C})$ & 38 & 41 \\
\hline Pollitt, Harry & $(\mathrm{b})(7)(\mathrm{C})$ & 40 & 43 \\
\hline Pollitt, Harry & $(\mathrm{b})(7)(\mathrm{C})$ & 41 & 44 \\
\hline Pollitt, Harry & $(\mathrm{b})(7)(\mathrm{C})$ & 41 & 45 \\
\hline Pollitt, Harry & $(\mathrm{b})(7)(\mathrm{C})$ & 42 & 45 \\
\hline Pollitt, Harry & $(\mathrm{b})(7)(\mathrm{C})$ & 42 & 46 \\
\hline Pollitt, Harry & $(\mathrm{b})(7)(\mathrm{C})$ & 44 & 47 \\
\hline Pollitt, Harry & $(\mathrm{b})(7)(\mathrm{C})$ & 45 & 48 \\
\hline Pollitt, Harry & $(\mathrm{b})(7)(\mathrm{C})$ & 45 & 49 \\
\hline Saul & $(\mathrm{b})(7)(\mathrm{C})$ & 34 & 37 \\
\hline Saul & $(\mathrm{b})(7)(\mathrm{C})$ & 35 & 38 \\
\hline Silverthorn, Special Agent & $(\mathrm{b})(7)(\mathrm{C})$ & 23 & 25 \\
\hline
\end{tabular}




\begin{tabular}{|c|c|c|c|}
\hline Stolzenberg & $(\mathrm{b})(7)(\mathrm{C})$ & 11 & 11 \\
\hline Swan, Willie & $(\mathrm{b})(7)(\mathrm{C})$ & 9 & 8 \\
\hline Swan, Willie & $(\mathrm{b})(7)(\mathrm{C})$ & 10 & 9 \\
\hline Swan, Willie & $(\mathrm{b})(7)(\mathrm{C})$ & 11 & 10 \\
\hline Swan, Willie & $(\mathrm{b})(7)(\mathrm{C})$ & 11 & 11 \\
\hline Thalheimer, August & (b)(7)(C) & 9 & 8 \\
\hline Thalheimer, August & (b)(7)(C) & 10 & 9 \\
\hline Ulbricht, Walter & $(\mathrm{b})(7)(\mathrm{C})$ & 9 & 8 \\
\hline Ulbricht, Walter & (b)(7)(C) & 10 & 10 \\
\hline Ulbricht, Walter & (b)(7)(C) & 18 & 19 \\
\hline Ulbricht, Walter & (b)(7)(C) & 51 & 55 \\
\hline Voroshilov, General Klimientiy & (b)(7)(C) & 31 & 34 \\
\hline Walter, Mrs. & (b)(7)(C) & 59 & 64 \\
\hline Wickman, Harry & (b)(7)(C) & 55 & 59 \\
\hline Wickman, Harry & (b)(7)(C) & 55 & 60 \\
\hline Wickman, Harry & (b)(7)(C) & 57 & 62 \\
\hline Wilhelm, Hans & (b)(7)(C) & 52 & 56 \\
\hline Wilhelm, Hans & (b)(7)(C) & 60 & 65 \\
\hline Wilhelm, Hans & (b)(7)(C) & 62 & 67 \\
\hline Wollenberger & (b)(7)(C) & 42 & 45 \\
\hline
\end{tabular}

Using simple ratio and proportion, in the 719 released pages, some 363 names were considered too dangerous for the public to see in documents as old as 80 years. Disturbing as this is, can we expect that there are names that any college-educated Department of Justice/FBI civil servant should have known as belonging to persons who had died — and thus were releasable? Counted here were:

Heinrich Brandler

Ruth Fischer 
InterAção | 175

\author{
Lavar Kaganovich \\ Otto Kuusinen \\ Dmitri Manuilski \\ Anastas Mikoyan \\ Vyacheslav Molotov \\ William Pieck \\ Harry Pollitt \\ August Thalheimer \\ Walter Ulbricht \\ General Klimientiy Voroshilov
}

Indeed, can we presume that the functionaries of the U.S. Department of Justice and FBI have ever taken an introductory course in 20th Century English, German, or Russian history during their college careers? How can the release of such identities be constituted to be, according to subsection $(\mathrm{b})(7)(\mathrm{C})$, "an unwarranted invasion of personal privacy" if the person is deceased? Is this not one of the criteria mentioned as a reason for releasing someone's name in the first place? If the onus of providing names of deceased person when first applying falls on the applicant, why then does the Department of Justice/FBI even need people to respond to their Freedom of Information Act applications? Could not a machine do the job just as well if not better than a human?

Certainly, the supervisors of such public servants are selected because they have at least a master's degree and/or have lived through the times at the Bureau when communism was enemy number one. Should they, if anyone, know that all of the above short-listed indivi- 
duals are dead? It is reasonable to believe that they should, but do not because of faulty selection procedures by the American Department of Justice and FBI in allocating supervising employees to the roles of Freedom of Information Act overseers. Moreover, to say that "after careful consideration" these superiors deem that their underlings have acted correctly in repressing a name is probably a falsehood. While some superiors actually read the requests and appeals that cross their desks, a more likely scenario is that the majority of superiors simply sign off without ever reading beyond the recommendations of underlings.

There is one final alternative. Could it be that the American government, in it labyrinth of competing security agencies, allows its records of who was on or is on the political left to influence what and how much material is released to the petitioner under the terms of the Freedom of Information Act? While we would hope that such is not the case, it is not beyond the realm of possibility in view of the items withheld in this study on Johnny de Graaf. Contributors might, accordingly, wish to think carefully about their own past, including their ties to Latin America, before requesting documents from the U.S. Department of Justice/FBI. It is vital to note, in this regard, that the selective availability of archival items impacts what we know and do not know about the past. In that vein, the forces controlling access to this information shape our collective memories and in so doing manipulate our history-not just in Latin America, but so too in the United States of America. 
InterAção | 177 